\title{
THE EFFECTIVENESS OF CELL PHONE-BASED MENTORING THROUGH SMS ON DIET COMPLIANCE AMONG TYPE 2 DIABETES MELLITUS (T2DM) PATIENTS
}

\author{
Ratna Dewi ${ }^{1 *}$, Rostinah Manurung2 ${ }^{2}$ Sarmaida Siregar ${ }^{3}$ \\ 1,2,3 Lecturer at Institute of Health Science Imelda Bilal Ujung Street No. 52, Medan, Indonesia \\ * Correspondence: ratnadewi2550@gmail.com
}

\begin{abstract}
Appropriate diet and physical exercise is part of diabetes management. The role of health professionals is critical to regulating the lifestyle of type $2 \mathrm{DM}$ patients. The study aimed at examining the effectiveness of cell phone-based mentoring on dietary compliance. A quasiexperimental study design, pre and post-test equivalent with the control group. The research was conducted at Bromo Medan Health Center. We recruited 84 diabetic patients and divided into the experimental and control group. The findings showed there was a positive effect on the patients in the experimental group who received the program than patients in the control group who did not receive the application. This strategy is essential and recommended to apply in the routine diet at home.
\end{abstract}

Keywords: short message service (SMS), diet compliance, type 2 diabetes mellitus

International Journal of Nursing and Health Services (IJNHS), September 2019, Volume 2, Issue 3; Page 135-141

Received: 10 June 2019; Revised: 30 July 2019; Accepted: 01 August 2019

DOI: http//doi.org/10.35654/ijnhs.v2i3.214

\section{Introduction}

Type 2 diabetes mellitus (DM) is known as a silent killer because it is often not recognized by the sufferer. Hyperglycemia that arises from time to time can cause damage to various body systems, especially nerves and blood vessels. Several complications of diabetes, including heart disease, stroke, neuropathy (nerve damage). Diabetes Mellitus also may impact on ulcers and lead to lower limb amputation(1). Behaviors become an essential factor in

diabetes mellitus. Thereby intervention focused on behavior practices needed to manage the complex lifestyle changes such as regular medication adherence, diet regulation, physical exercise, monitoring of blood glucose, and foot care (2).

According to Indonesian Endocrinology Association, five pillars of diabetes management are required, including education, dietary management, physical exercise, 
pharmacological, or drug therapy. Routine blood glucose checking also crucial for controlling blood glucose (3).

Patient compliance is needed to achieve therapeutic success, especially for noncommunicable diseases such as DM and other diseases. According to Sarafino and Smith, that non-compliance increases the risk of developing health problems or prolonging or worsening the pain being suffered (4). Factors that influence a person's adherence to treatment are officer factors, drug factors, and patient factors. Characteristics of officers who control compliance include the type of officer, level of knowledge, length of work, frequency of counseling conducted.

According to Tera, found that health workers have a vital role in efforts to increase knowledge of DM patients to improve patient compliance in following DM care (5). These efforts can be made with education and counseling. In line with Adyani, health workers can change patient control to be more positive by educating patients that the importance of monitoring and self-awareness to take actions that aim to improve their health, so that in itself can improve adherence in DM care, especially DM management (6)

The Healthy Indonesia Program in the period 2015-2019 is directed to focus on one of which is to overcome Non-Communicable Diseases (PTM), among others, DM by increasing the early detection of PTM risk factors through integrated coaching posts (Posbindu) and access to integrated PTM services at first-level health facilities. Namely puskesmas through education and counseling (7). Education and advice can be enhanced by mentoring activities which are activities carried out and can mean coaching, teaching, the direction in groups that are more connotation of mastering, controlling, and controlling (8).

One method of education is through mentoring models with the use of mobile phones. High flexibility and accessibility support the importance of cellular phone use in improving public health, primarily through Short Message Service (SMS) reminder (9). Based on the results of research by Krishna and Boren, found that in the use of SMS is very useful in increasing the compliance of DM patients in following DM treatment recommendations so that KGD becomes controlled (10). In line with the research of Russell et al., states that support or companion through the use of SMS cell phones improves selfmanagement of DM patients (11).

Although the Bromo Health Center has become the organizer of the Chronic Disease Management Program but based on the preliminary survey conducted at the study site through secondary data in the form of a card recording the attendance of patients during the visit, it showed that out of 94 people registered as patients who had visited the Puskesmas to access related services with type 2 diabetes, only 22 people were found to be present every week to control blood sugar levels (12-13). The rest sometimes attend, and some only come once and never come again to access services related to the prevention of type 2 DM.

\section{Objectives}

The study aimed to examine the effectiveness of cell phone-based mentoring on dietary compliance among patients with type 2 diabetes mellitus. 


\section{Method}

We applied quasi-experimental study design, pre-test, and post-test equivalent to the control group. The study population was all type 2 DM patients who came to Bromo Health Center from July to December 2017. Eighty-four total samples were recruited and divided into an experimental group $(n=42)$ and control group $(n=42)$.

We provided the mentoring interventions by SMS five times a week in the intervention group for four weeks. Before data collecting, the researcher explained the objective of this study, procedures, and definite advantages of the study. We also asked them to sign informed consent if they were a willingness to join this study. Data collection was carried out before and after the intervention, directly from respondents based on diet compliance questionnaires developed based on Indonesian Endocrinology Association nutrition therapy and the Indonesian Ministry of Health. Data analysis using Wilcoxon test and Mann Whitney test.

\section{Result}

4.1. Frequency Distribution of Type 2 DM Patients Based on Diet Compliance Scores Before Health Counseling about DM and SMS Mentoring

Table 1. Frequency Distribution of Type 2 DM Patients Based on Diet Compliance Scores Before Health Counseling DM and SMS Mentoring $(\mathrm{n}=42)$

\begin{tabular}{lcccc}
\hline \multirow{2}{*}{ Obedience } & \multicolumn{2}{c}{ Intervention Group } & \multicolumn{2}{c}{ Control Group } \\
\cline { 2 - 5 } & $\mathrm{f}$ & $\%$ & $\mathrm{f}$ & $\%$ \\
\hline Diet & & & & \\
1. Obey & 10 & 23,8 & 19 & 54,8 \\
2. Not Obey & 32 & 76,2 & 23 & 45,2 \\
Total & 42 & 100 & 42 & 100 \\
\hline
\end{tabular}

\subsection{Frequency Distribution of Type 2 DM Patients Based on Diet Compliance Score After Health Counseling DM and SMS Mentoring}

Table 2. Frequency Distribution of Type 2 DM Patients Based on Diet Compliance After Health Counseling about DM and SMS Mentoring $(n=42)$

\begin{tabular}{lcccc}
\hline \multirow{2}{*}{ Obedience } & \multicolumn{2}{c}{ Intervention Group } & \multicolumn{2}{c}{ Control Group } \\
\cline { 2 - 5 } & $\mathrm{f}$ & $\%$ & $\mathrm{f}$ & $\%$ \\
\hline Diet & & & & \\
1. Obey & 29 & 69 & 22 & 52,4 \\
2. Not Obey & 13 & 31 & 20 & 47,6 \\
Total & 42 & 100 & 42 & 100 \\
\hline
\end{tabular}




\subsection{Distribution of Differences in Average in Diet Compliance Scores Before and After Health Counseling about DM and Mentoring Through SMS Intervention Groups}

Table 3. Distribution of Differences in Average in Diet Compliance Scores Before and After Health Counseling About DM and Mentoring Through SMS Intervention Groups $(n=42)$

\begin{tabular}{lccc}
\hline \multirow{2}{*}{ Obedience } & \multicolumn{2}{c}{ Mean } & $p$ \\
\cline { 2 - 3 } & Before & After & \\
\hline Diet & 8,17 & 10,17 & 0,001 \\
\hline
\end{tabular}

Table 3. The intervention group showed that there were differences between before and after health education about DM disease and SMS assistance on dietary compliance (difference in mean $2 ; \mathrm{p}<0.05)$.

\subsection{Distribution of Differences in Average in Diet Compliance Score Before and After Health Counseling about DM Control Group}

Table 4. Distribution of Differences in Average in Diet Compliance Scores Before and After Health Counseling About DM Control Group (42)

\begin{tabular}{lccc}
\hline \multirow{2}{*}{ Obedience } & \multicolumn{2}{c}{ Mean } & $p$ \\
\cline { 2 - 3 } & Before & After & \\
\hline Diet & 9,02 & 9,19 & 0,083 \\
\hline
\end{tabular}

Table 4. The control group showed that there was no difference between before and after health education about DM disease on dietary compliance (difference in mean $0.17 ; \mathrm{p}>0.05$ ).

4.5. Distribution of Differences in Diet Compliance in Intervention Groups After Health Counseling and Companion Through SMS and Control Groups After Health Counseling DM

Table 5.

Distribution of Differences in Diet Compliance in Intervention Groups After Health Counseling and Companion Through SMS and Control Groups After Health Counseling DM

\begin{tabular}{lccc}
\hline Obedience & \multicolumn{2}{c}{ Mean Rank } & after Intervention \\
\cline { 2 - 4 } & Intervention & Control & \\
\hline Diet & 37,36 & 47,64 & 0,047 \\
\hline
\end{tabular}

Table 5 showed there was a significant difference in diet scores between the intervention group and the control group after receiving the program $(\mathrm{p}<0.05)$. 


\section{Discussion}

\section{Differences in Diet Compliance Scores Before and After Health Counseling and Mentoring Through SMS in Intervention Groups and Control Groups}

The Wilcoxon test showed that patients in the intervention group were higher of the mean score of dietary adherence after receiving the intervention than before receiving the intervention. Also, the ratings were higher among patients who received the intervention group compared those control group

who did not receive the intervention. The result was consistent with the previous study mentioned that patients who received the three days intervention via SMS were a significant difference in dietary behaviors (14). Another study also showed the positive effects of intervention via SMS on nutritional status among hemodialysis patients (15). While the results of the research by Silina et al found a statistically significant weight loss in overweight cardiovascular patients after sending SMS about health care (16). Another study also reported that folow-up using a telephone or computer-based follow-up has positive effect on sustaining self-management behaviors and decreasing HbAlc (17-18).

In conclusion, the increase in dietary compliance among diabetes patient, the sufficient knowledge about the appropriate diet includes regularity of schedule, and the amount of calorie content was needed. Interprofessional collaboration doctors, nutritionists, other health workers, and patients and their families become a crucial point for managing diabetes and control blood glucose level.

\section{The difference in Diet Compliance Score After Health Counseling and SMS Guidance at Intervention Groups and Control Groups}

Based on the Mann Whitney test, the results showed that there were significant differences in dietary compliance after receiving health education $(p<0,05)$. One method of education is through mentoring models with the use of mobile phones. High flexibility and accessibility support the importance of cellular phone use in improving public health, primarily through Short Message Service (SMS) reminder (8). A study showed the positive effect of compliance behavior after receiving intervention using telephone message (19). It was consistent with the study by Rahmah et al. Confirmed that intervened in sending SMS every three days has positive effects on health outcomes (14). The results of the study conducted by Widiany and Afriani also confirmed the positive impact on the nutritional status of hemodialysis patients (15).

\section{Conclusions}

In conclusion, Cell phone-based mentoring through SMS was a positive effect on improving diet compliance among type 2 diabetes mellitus (T2DM) patients. Further study needed to design some strategy by involving family members to support patients in diabetes care, especially at home. 


\section{References}

1. Republic of Indonesia Ministry of Health. (2014). Basic health research report. Jakarta, Data and Information Center

2. Chang L, Chao Y, \& Chen. The effectiveness of a diabetes self-management program for diabetes patients in Taiwan. International Journal of Research in Medical and Health Sciences. Vol. 4, No. 4, 2014.

3. Indonesian Endocrinology Association. (2015). Consensus Management and Prevention of Type 2 DM in Indonesian. Jakarta, Indonesian Endocrinology Association.

4. Sarafino PE, \& Smith WT. (2011). Health Psychology; Biopsychosocial Interaction. Seventh Edition, Wiley.

5. Tera BHA. Determinants of Non-Compliance with Diets of Type 2 Diabetes Mellitus Patients. (2011). http://eprints.undip.ac.id/32591/1/393.Banu_Hanifah_Al_Tera_G2C007014.pdf.

6. Adyani I. Relationship between health locus of control and adherence to the management of a type 2 DM diet in the DM association in Puskesmas III, North Denpasar. (2015). Google scholar 13943-35941-1-PB.

7. Republic of Indonesia Ministry of Health. (2016). General Guidelines for a Healthy Indonesia Program with a Family Approach. Jakarta, Healthy Indonesia Program.

8. Subagyo H. Effect of the Role of Assisting Village Midwives on the Development of Alert Villages. (2008). https://eprints.uns.ac.id/5356/1/7380090720090 4461.pdf.

9. Herlina S, Sanjaya GY, \& Emilia O. Utilization of Cellular Phone SMS Facility as a Health Promotion Media for Pregnant Women in Remote Areas. Indonesian Information System National Seminar, 2-4 December 2013.

10. Krishna S, \& Boren SA. Diabetes Self Management Care via Cell Phone: A Systematic Review. Journal of Diabetes Science and Technology, Volume 2, Issue 3 May 2008@Diabetes Technology Society.

11. Russel NM, Vess J, Durham C, \& Johnson E. Text-Messaging to Support Diabetes Self Management in a Rural Health Clinic: A Quality Improvement Project. Online Journal of Nursing Informatics (OJNI), 21(2), 2017, Available at http://www.himss.org/ojni.

12. Health Insurance Organizing Agency. (2014). Chronic Disease Management Program Practical Guide. Jakarta, BPJS.

13. Republic of Indonesian Ministry of Health. (2011). Diabetes Mellitus Diet. Jakarta, Directorate of Nutrition Development for Clinical Nutrition Development.

14. Rahmah PA, Galistiani GF, \& Kusuma AM. Effect of Short Message Service (SMS) on the compliance of medication and lifestyle of diabetes mellitus patients in the RSUD DR. A. Sari Pemalang. Pharmaceutical Media, Vol. 13 No. 1 Maret 2016: 110-121.

15. Widiany FL, \& Afriani Y. Provision of SMS Reminders Effectively Improves Nutritional Status Anthropometry of Hemodialysis Patients. Indonesian Nutrition Science, pISSN 2580419X, Vol. 01, No. 01. 2017.

16. Silina V, Mesfin K, Tessma, Senkane S, Krievina G, \& Bahs G. Text Messaging (SMS) as a Tool to Facilitate Weight Loss and Prevent Metabolic Deterioration in Clinically Health Overweight and Obese Subjects: a Randomised Controlled Trial. Scandinavian Journal of Primary Health Care. Volume 35. 2017-issue 3. 
17. Pamungkas RA, Chamroonsawasdi K, Vatanasamboon P. A systematic review: family support integrated with diabetes self-management among uncontrolled type II diabetes mellitus patients. Behav Sci. 2017; 7(3): 62

18. Pamungkas RA, Chamroonsawasdi K. HbA1c reduction and weight-loss outcomes: a systematic review and meta-analysis of community - based intervention trials among patients with type 2 diabetes mellitus. International Journal of Diabetes in Developing Countries. 2019; 39(2): 394-407

19. Laksono B, Yuniastuti A, \& Chikmah AM. Short Massage Service (SMS) Effectiveness of Mother Compared to Class of Toddler Mother Against Increased Knowledge, Attitude, Behavior. Public Health Perspective Journal. 2016; 1(1). http://journal. unnes.ac.id/sju/index.php/phpj. 